\title{
Thermodynamics of Titanium and Oxygen Dissolved in Liquid Iron Equilibrated with Titanium 0xides
}

\author{
Jong-Jin PAK, ${ }^{11}$ Jong-Oh JO, ${ }^{11}$ Sun-In KIM, ${ }^{1)}$ Wan-Yi KIM, ${ }^{11}$ Tae-In CHUNG, ${ }^{11}$ Seok-Min SEO, ${ }^{21}$ \\ Joo-Hyun PARK ${ }^{3)}$ and Dong-Sik KIM ${ }^{3 \prime}$ \\ 1) Division of Materials and Chemical Engineering, Hanyang University, Ansan 426-791, Korea. E-mail: jjpark@hanyang.ac.kr \\ 2) Formerly Graduate Student, Division of Materials and Chemical Engineering, Hanyang University. Now at SeAH Besteel \\ Co., Ltd., Kunsan 573-711, Korea. \\ 3) Technical Research Laboratories, POSCO, Pohang 790-690, Korea.
}

(Received on May 19, 2006; accepted on September 20, 2006)

The equilibrium relation of $\mathrm{Ti}$ and $\mathrm{O}$ dissolved in liquid iron saturated with solid titanium oxides was measured in the temperature range of 1823 to $1923 \mathrm{~K}$. Pure $\mathrm{Ti}_{2} \mathrm{O}_{3}(\mathrm{~s})$ phase was identified as the equilibrium deoxidation product for iron melts containing $0.25-4.75$ mass \% Ti. Using Wagner's formalism, the present results were thermodynamically analyzed to determine the equilibrium constant of $\mathrm{Ti}$ deoxidation reaction for the formation of pure $\mathrm{Ti}_{2} \mathrm{O}_{3}(\mathrm{~s})$ and the first- and second-order interaction parameters between $\mathrm{Ti}$ and $\mathrm{O}$ given as follows in the temperature range of 1823 to $1923 \mathrm{~K}$.

$$
\begin{gathered}
2 \underline{\mathrm{Ti}}+3 \underline{\mathrm{O}}=\mathrm{Ti}_{2} \mathrm{O}_{3}(\mathrm{~s}) \quad(0.25<\text { mass } \% \mathrm{Ti}<4.75) \\
\log K_{\mathrm{T}_{2} \mathrm{O}_{3}}=44238 / T-13.0 \\
e_{\mathrm{O}}^{\mathrm{T}}=-1642 / T+0.3358, \quad e_{\mathrm{T}_{\mathrm{T}}}^{\mathrm{O}}=-4915 / T+1.005 \\
r_{\mathrm{O}}^{\mathrm{T}}=0.0385, \quad r_{\mathrm{Ti}}^{\mathrm{O}}=-0.355
\end{gathered}
$$

The equilibrium titanium oxide phase was identified as $\mathrm{Ti}_{3} \mathrm{O}_{5}$ (s) for iron melts containing $0.0012-0.25$ mass $\% \mathrm{Ti}$ at $1873 \mathrm{~K}$. The equilibrium constant of $\mathrm{Ti}$ deoxidation reaction for the formation of pure $\mathrm{Ti}_{3} \mathrm{O}_{5}(\mathrm{~s})$ were estimated as follows.

$$
\begin{gathered}
3 \underline{\underline{T}+5 \underline{\mathrm{O}}=}=\mathrm{Ti}_{3} \mathrm{O}_{5}(\mathrm{~s}) \quad(0.0012<\text { mass } \% \mathrm{Ti}<0.25) \\
\log K_{\mathrm{Ti}_{3} \mathrm{O}_{5}}=72813 / T-21.32
\end{gathered}
$$

The activity coefficient of $\mathrm{Ti}$ in liquid iron at infinite dilution, $\gamma_{\mathrm{T}(\mathrm{s})}^{\circ}$ was assessed as $0.011,0.014$ and 0.018 at $1823 \mathrm{~K}, 1873 \mathrm{~K}$ and $1923 \mathrm{~K}$, respectively.

KEY WORDS: liquid iron; deoxidation; titanium; oxygen; titanium oxides; equilibrium constant; interaction parameter.

\section{Introduction}

Titanium is added in many high grade steels to improve mechanical properties via the grain refinement during hot rolling. Also, Ti is an important alloying element in ferritic stainless steels to stabilize $\mathrm{C}$ and $\mathrm{N}$, and hence to improve the intergranular corrosion resistance of the weld. ${ }^{1)}$ Therefore, thermodynamics of $\mathrm{Ti}$ and $\mathrm{O}$ dissolved in liquid steel is very important for the precise control of Ti content in the steelmaking process.

Titanium is very reactive for $\mathrm{O}$, and the titanium oxide as an equilibrium deoxidation product changes its chemical composition with Ti content in liquid steel. ${ }^{2-10)}$ Due to experimental difficulties, in spite of its importance, there are large discrepancies in thermodynamic data of the Ti deoxidation equilibria in liquid $\mathrm{Fe}-\mathrm{Ti}-\mathrm{O}$ system at $1873 \mathrm{~K}$ previously reported. ${ }^{2-12)}$ Furthermore, the temperature dependencies of those data are not available.

In the present study, the deoxidation equilibrium between
$\mathrm{Ti}$ and $\mathrm{O}$ in liquid iron in contact with titanium oxide powder of a crucible form or in an $\mathrm{Al}_{2} \mathrm{O}_{3}$ crucible was studied in the temperature range of 1823 to $1923 \mathrm{~K}$ using a high frequency induction furnace. After each equilibration experiment, the titanium oxides near the oxide/metal interface were analyzed by the X-ray diffraction (XRD) and the electron prove micro-analyzer (EPMA) analysis for the phase identification and the composition analysis, respectively. The measured equilibrium relation of $\mathrm{Ti}$ and $\mathrm{O}$ in liquid iron was thermodynamically analyzed using Wagner's formalism ${ }^{13)}$ to determine the equilibrium constant of Ti deoxidation reaction in liquid iron for the formation of pure $\mathrm{Ti}_{2} \mathrm{O}_{3}(\mathrm{~s})$ and the first- and second-order interaction parameters between $\mathrm{Ti}$ and $\mathrm{O}$ as a function of temperature. Using available thermochemical tables, ${ }^{14,15)}$ the equilibrium constant of $\mathrm{Ti}$ deoxidation reaction for the formation of pure $\mathrm{Ti}_{3} \mathrm{O}_{5}(\mathrm{~s})$ and the activity coefficient of $\mathrm{Ti}$ in liquid iron at infinite dilution, $\gamma_{\mathrm{Ti}(\mathrm{s})}^{\circ}$ were also assessed as a function of temperature. 


\section{Experimental Procedures}

One hundred grams of high purity electrolytic iron (99.99\% purity, 60 mass ppm O, <5 mass ppm N, 18 mass ppm $\mathrm{C},<5$ mass ppm Si, $<7$ mass ppm Ni, 1 mass ppm $\mathrm{Al}$ ), contained in a mixture of solid $\mathrm{Ti}_{2} \mathrm{O}_{3}$ and $\mathrm{TiO}_{2}$ powders (1: 1 molar ratio, $99.9 \%$ and $99 \%$ purity, respectively) of a crucible form in an $\mathrm{Al}_{2} \mathrm{O}_{3}$ crucible (OD: $40 \mathrm{~mm}$, ID: $30 \mathrm{~mm}, \mathrm{H}: 50 \mathrm{~mm}$ ), was melted using a $15 \mathrm{~kW} / 30 \mathrm{kHz}$ high frequency induction furnace as shown in Fig. 1. In some experiments, an $\mathrm{Al}_{2} \mathrm{O}_{3}$ crucible was used for melting the iron. In that case, a mixture of solid $\mathrm{Ti}_{2} \mathrm{O}_{3}$ and $\mathrm{TiO}_{2}$ powders $\left(1: 1\right.$ molar ratio) was located at the bottom of $\mathrm{Al}_{2} \mathrm{O}_{3}$ crucible. Figure 2 shows the XRD pattern for a mixture of solid $\mathrm{Ti}_{2} \mathrm{O}_{3}$ and $\mathrm{TiO}_{2}$ powders used in the present study.

The reaction chamber consisted of a $80 \mathrm{~mm}$ OD quartz tube open at both ends and was connected to a gas delivery system. The flow rate of $\mathrm{Ar}+3 \mathrm{vol} \% \mathrm{H}_{2}$ gas mixture, which was dehydrated by magnesium perchlorate, was in the range of 100 to $150 \mathrm{~mL} / \mathrm{min}$. In order to remove any residual oxygen in the reaction chamber during heating, the mixture of $\mathrm{Ti}$ chips and $\mathrm{MgO}$ granules was packed in the space

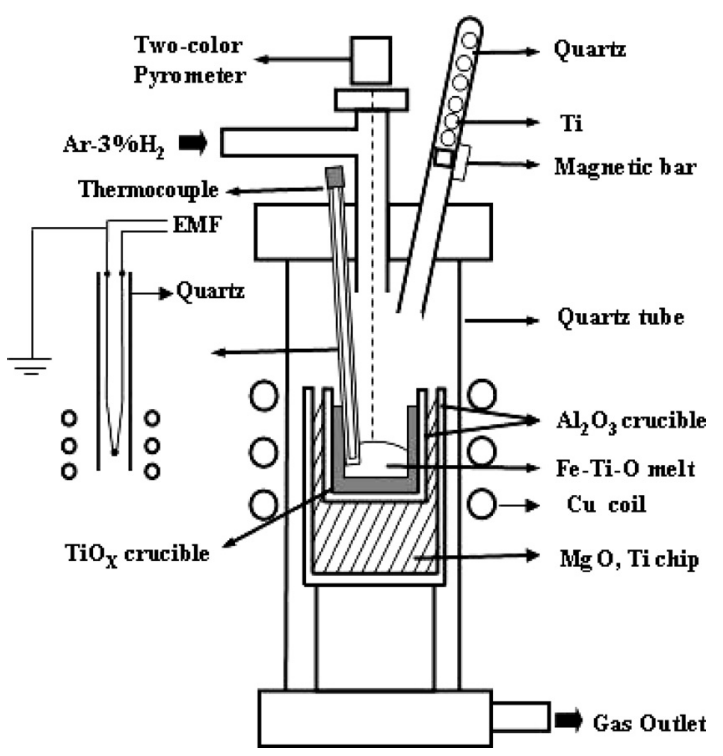

Fig. 1. Schematic diagram of experimental system.

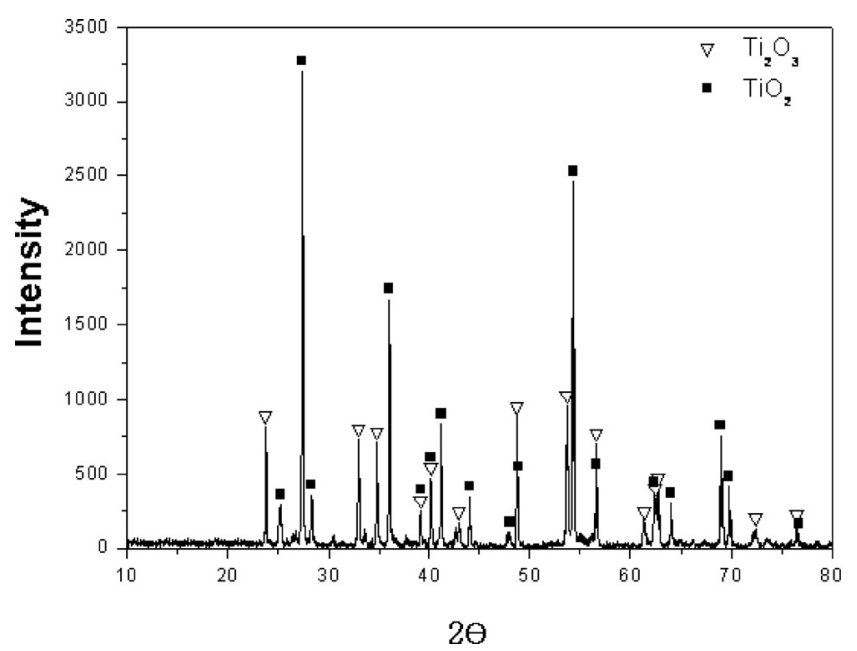

Fig. 2. XRD pattern for a mixture of solid $\mathrm{Ti}_{2} \mathrm{O}_{3}$ and $\mathrm{TiO}_{2}$ powders before melting the iron. between the inner and outer $\mathrm{Al}_{2} \mathrm{O}_{3}$ crucibles. A detailed description of the experimental system is given in the previous article. ${ }^{16)}$

After melting the iron, sponge Ti (99.5\% purity) metal, which was kept in a glass tube by a magnet, was dropped into liquid iron. The melt temperature was measured by a $\mathrm{Pt} / \mathrm{Pt}-13 \mathrm{mass} \% \mathrm{Rh}$ thermocouple sheathed by a $5 \mathrm{~mm}$ OD quartz tube immersed in the melt. In order to minimize $\mathrm{Si}$ pick up in the melt by the reduction of quartz tube, the immersion depth and the time for temperature measurement were carefully controlled after Ti addition. Any possible influence of high frequency noise on the temperature reading was avoided by grounding the circuit of the thermocouple. Preliminary trials confirmed that no significant noise was detected, and the temperature fluctuation of iron melt could be controlled within $5 \mathrm{~K}$ during experiment. Strong agitation of melt by an induction furnace would result in a faster attainment of deoxidation equilibrium and a good separation of deoxidation products from the melt. The iron melts were equilibrated with titanium oxides for $1 \mathrm{~h}$ under an $\mathrm{Ar}+3 \mathrm{vol} \% \mathrm{H}_{2}$ atmosphere at $1823 \mathrm{~K}, 1873 \mathrm{~K}$ and $1923 \mathrm{~K}$.

After each experiment, iron sample and crucible were quenched rapidly by helium gas of high flow rate $(>50 \mathrm{~L} / \mathrm{min})$ blowing onto the melt surface. Figure 3 shows the iron sample contained in a crucible of sintered titanium oxide powder obtained after experiment. After each experiment, the titanium oxide layer near the oxide/metal interface was sampled and analyzed by the XRD for the phase identification. The EPMA analysis was also carried out for the composition analysis of the titanium oxide layer. In those experiments using $\mathrm{Al}_{2} \mathrm{O}_{3}$ crucibles with titanium oxide powder, the inner surface of $\mathrm{Al}_{2} \mathrm{O}_{3}$ crucible and the melt surface were examined by the SEM-EDS and analyzed by the thin film XRD for the identification of Ti deoxidation product.

The center part of metal sample was used for the chemical analysis of Ti, Al, Si and O. The metal sample $(0.2 \mathrm{~g})$ was dissolved in $15 \mathrm{~mL}$ of $\mathrm{HCl}(1+1)$ and $5 \mathrm{~mL}$ of $\mathrm{HNO}_{3}(1+1)$ in a glass beaker of $50 \mathrm{~mL}$ capacity heated in a water bath for $2 \mathrm{~h}$. The leaching test of titanium oxide powders $\left(\mathrm{Ti}_{2} \mathrm{O}_{3}\right.$ and $\left.\mathrm{Ti}_{3} \mathrm{O}_{5}\right)$ indicated that they were nearly insoluble in aqua regia solution heated in a water bath up to $12 \mathrm{~h}$. After dissolving the sample, the solution was transferred to the measuring flask $(100 \mathrm{~mL})$ with filtration. Titanium, aluminum and silicon contents in sample solution were analyzed by the inductively coupled plasma-Auger electron spectroscopy (ICP-AES) technique using appropriate standard solutions containing the same amount of $\mathrm{Fe}$ (2000 mass ppm) as sample solution. The oxygen content in metal sample was measured with an accuracy of \pm 1

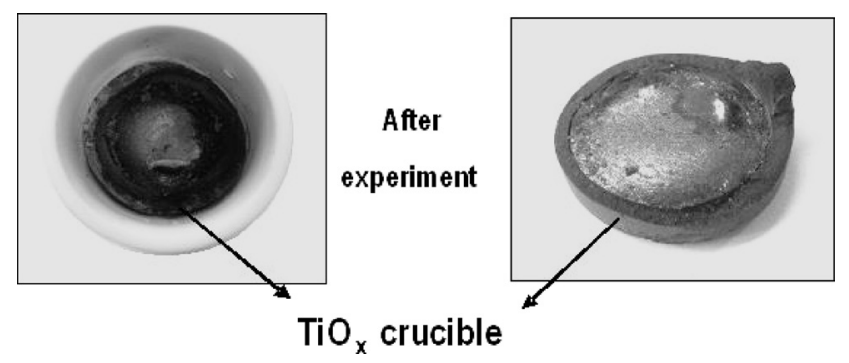

Fig. 3. Iron sample contained in a titanium oxide crucible. 
Table 1. The experimental results of $\mathrm{Ti}$ and $\mathrm{O}$ equilibration in iron melt.

\begin{tabular}{|c|c|c|c|c|c|c|c|}
\hline $\begin{array}{l}\text { Test } \\
\text { No. }\end{array}$ & $\begin{array}{c}\text { Temp. } \\
\left({ }^{\circ} \mathrm{K}\right)\end{array}$ & Crucible & {$[\% \mathrm{Ti}]$} & {$[\% \mathrm{Si}]$} & {$[\% \mathrm{Al}]$} & {$[\mathrm{O}] \mathrm{ppm}$} & $\begin{array}{c}\text { Equilibrium } \\
\text { phase }\end{array}$ \\
\hline 1 & \multirow{45}{*}{1873} & \multirow{7}{*}{$\mathrm{TiO}_{\mathrm{x}}$} & 0.0012 & 0.0679 & - & 64.7 & \multirow{4}{*}{$\mathrm{Ti}_{3} \mathrm{O}_{5}$} \\
\hline 2 & & & 0.0024 & 0.0607 & - & 45.8 & \\
\hline 3 & & & 0.0100 & 0.0815 & - & 28.9 & \\
\hline 4 & & & 0.1502 & 0.0685 & - & 12 & \\
\hline 5 & & & 0.2601 & 0.0532 & - & 10 & \multirow{3}{*}{$\mathrm{Ti}_{2} \mathrm{O}_{3}$} \\
\hline 6 & & & 0.5168 & 0.0289 & - & 9 & \\
\hline 7 & & & 1.470 & 0.0301 & - & 10.5 & \\
\hline 8 & & \multirow{38}{*}{$\begin{array}{l}\mathrm{Al}_{2} \mathrm{O}_{3}{ }^{*} \\
\left(\mathrm{TiO}_{\mathrm{x}}\right)\end{array}$} & 0.0057 & 0.0226 & - & 30.7 & \multirow{24}{*}{$\mathrm{Ti}_{3} \mathrm{O}_{5}$} \\
\hline 9 & & & 0.0059 & 0.0214 & - & 38.2 & \\
\hline 10 & & & 0.0276 & 0.0197 & - & 21.1 & \\
\hline 11 & & & 0.0291 & 0.0211 & - & 20.2 & \\
\hline 12 & & & 0.0332 & 0.0259 & - & 21 & \\
\hline 13 & & & 0.0369 & 0.0222 & - & 19.9 & \\
\hline 14 & & & 0.0395 & 0.0429 & - & 16.9 & \\
\hline 15 & & & 0.0476 & 0.0021 & 0.0022 & 16.5 & \\
\hline 16 & & & 0.0493 & 0.0034 & 0.0014 & 15.2 & \\
\hline 17 & & & 0.0535 & 0.0220 & - & 17.4 & \\
\hline 18 & & & 0.0811 & 0.0143 & 0.0020 & 13.3 & \\
\hline 19 & & & 0.0885 & 0.0022 & 0.0024 & 9.3 & \\
\hline 20 & & & 0.0888 & 0.0429 & 0.0024 & 10.8 & \\
\hline 21 & & & 0.0934 & 0.0498 & 0.0008 & 10.7 & \\
\hline 22 & & & 0.1022 & 0.0220 & 0.0003 & 9.50 & \\
\hline 23 & & & 0.1119 & 0.0165 & 0.0006 & 10.9 & \\
\hline 24 & & & 0.1185 & 0.0325 & 0.0043 & 10.3 & \\
\hline 25 & & & 0.1245 & 0.0478 & 0.0007 & 9 & \\
\hline 26 & & & 0.1469 & 0.0235 & 0.0080 & 11 & \\
\hline 27 & & & 0.1656 & 0.0390 & 0.0029 & 8.7 & \\
\hline 28 & & & 0.1782 & 0.0296 & 0.0038 & 11.5 & \\
\hline 29 & & & 0.1903 & 0.0334 & 0.0034 & 10.9 & \\
\hline 30 & & & 0.1925 & 0.0155 & 0.0036 & 10.8 & \\
\hline 31 & & & 0.2153 & 0.0221 & 0.0055 & 9.6 & \\
\hline 32 & & & 0.2576 & 0.0168 & 0.0113 & 8.5 & $\mathrm{Ti}_{3} \mathrm{O}_{5}, \mathrm{Ti}_{2} \mathrm{O}_{3}$ \\
\hline 33 & & & 0.3034 & 0.0140 & 0.0059 & 8.8 & \multirow{29}{*}{$\mathrm{Ti}_{2} \mathrm{O}_{3}$} \\
\hline 34 & & & 0.3140 & 0.0205 & 0.0076 & 10 & \\
\hline 35 & & & 0.3321 & 0.0191 & 0.0087 & 8.8 & \\
\hline 36 & & & 0.3562 & 0.0170 & 0.0049 & 9.6 & \\
\hline 37 & & & 0.3949 & 0.0186 & 0.0093 & 9.2 & \\
\hline 38 & & & 0.4503 & 0.0279 & 0.0041 & 9.2 & \\
\hline 39 & & & 0.5189 & 0.0324 & 0.0040 & 8.7 & \\
\hline 40 & & & 0.6248 & 0.0293 & 0.0045 & 7.7 & \\
\hline 41 & & & 0.6514 & 0.0113 & 0.0044 & 8 & \\
\hline 42 & & & 0.9378 & 0.0246 & 0.0038 & 9.3 & \\
\hline 43 & & & 1.762 & 0.0125 & 0.0130 & 12.5 & \\
\hline 44 & & & 2.766 & 0.0110 & 0.0100 & 19.1 & \\
\hline 45 & & & 3.612 & 0.0150 & 0.0120 & 26.5 & \\
\hline 46 & \multirow{7}{*}{1823} & \multirow{7}{*}{$\mathrm{TiO}_{\mathrm{x}}$} & 0.5947 & 0.0216 & - & 5.1 & \\
\hline 47 & & & 0.6179 & 0.0262 & - & 5.2 & \\
\hline 48 & & & 0.9308 & 0.0142 & - & 6.1 & \\
\hline 49 & & & 1.772 & 0.0176 & - & 10.6 & \\
\hline 50 & & & 2.845 & 0.0277 & - & 13.8 & \\
\hline 51 & & & 3.839 & 0.0744 & - & 19.9 & \\
\hline 52 & & & 4.451 & 0.0336 & - & 28 & \\
\hline 53 & \multirow{9}{*}{1923} & \multirow{9}{*}{$\mathrm{TiO}_{\mathrm{x}}$} & 0.4213 & 0.0562 & - & 13.2 & \\
\hline 54 & & & 0.4365 & 0.0423 & - & 13.3 & \\
\hline 55 & & & 0.5945 & 0.0183 & - & 12.7 & \\
\hline 56 & & & 0.9429 & 0.0323 & - & 14.6 & \\
\hline 57 & & & 1.140 & 0.0299 & - & 14.9 & \\
\hline 58 & & & 1.564 & 0.0685 & - & 21.1 & \\
\hline 59 & & & 2.622 & 0.0863 & - & 26.8 & \\
\hline 60 & & & 3.644 & 0.0311 & - & 42.7 & \\
\hline 61 & & & 4.746 & 0.0633 & - & 53.6 & \\
\hline
\end{tabular}

* $\mathrm{TiO}_{\mathrm{x}}$ powder at the bottom of $\mathrm{Al}_{2} \mathrm{O}_{3}$ Crucible

mass ppm by the inert gas fusion-infrared absorptiometry technique using the standard sample of steel containing $11 \pm 1$ mass ppm oxygen.

\section{Results and Discussion}

\subsection{Equilibrium Ti-O Relation and $\mathrm{TiO}_{x}$ Phase Iden- tification}

The results of Ti deoxidation experiments for liquid iron in contact with titanium oxides are summarized in Table 1. Small amount of Si was picked up in the melt by the reduc-

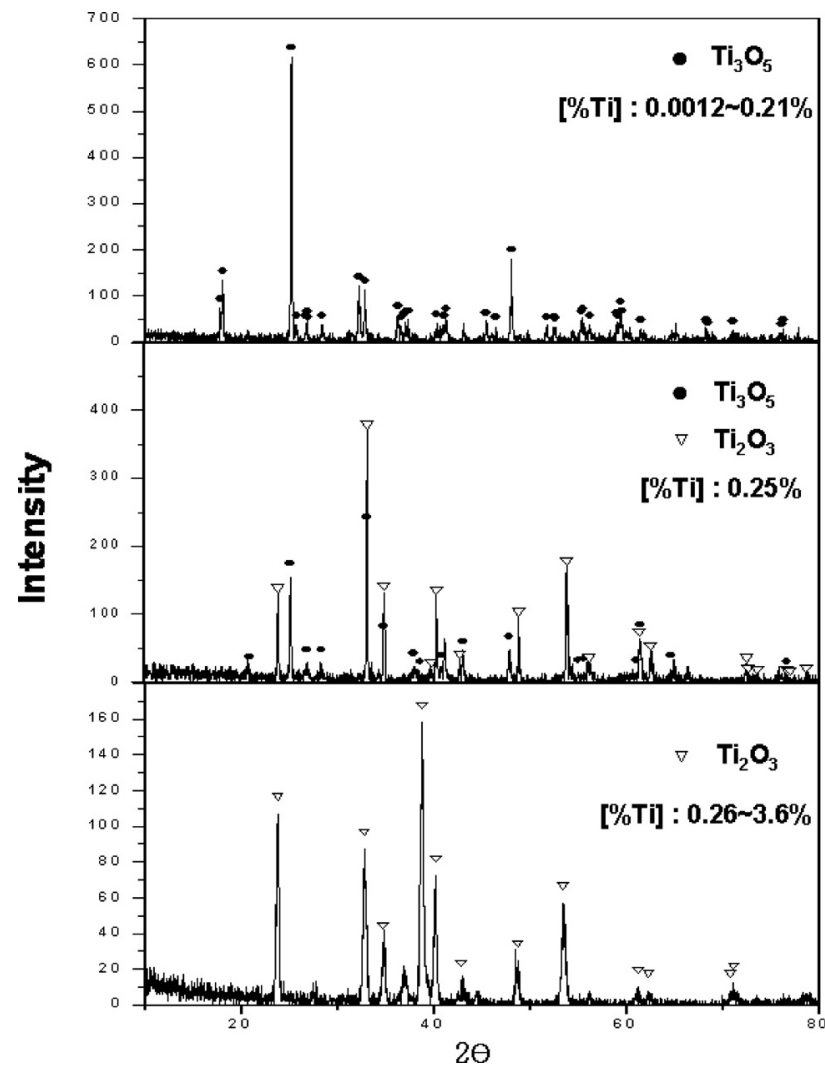

Fig. 4. XRD patterns for titanium oxide layers near the $\mathrm{TiO}_{x}$ crucible/metal interface.

tion of quartz tube immersed in the melt for the temperature measurement. When the melt was contained in an $\mathrm{Al}_{2} \mathrm{O}_{3}$ crucible with titanium oxide powder at the bottom of the melt, small amount of Al was picked up. However, Al was not detected in the melt when the melt was contained in a crucible of titanium oxide powder.

Figure 4 shows the results of XRD analysis on the titanium oxide layers near the oxide/metal interface after the $\mathrm{Ti}$ deoxidation experiments. The XRD pattern for a mixture of solid $\mathrm{Ti}_{2} \mathrm{O}_{3}$ and $\mathrm{TiO}_{2}$ powders shown in Fig. 2 has changed to new patterns of equilibrium titanium oxides. As shown in the figure, the equilibrium titanium oxide phase was identified as $\mathrm{Ti}_{3} \mathrm{O}_{5}$ for $\mathrm{Fe}-\mathrm{Ti}$ alloys containing from 0.0012 to 0.21 mass $\% \mathrm{Ti}$, and $\mathrm{Ti}_{2} \mathrm{O}_{3}$ for alloys containing from 0.26 to $3.6 \mathrm{mass} \% \mathrm{Ti}$ at $1873 \mathrm{~K}$. For an alloy containing 0.25 mass $\% \mathrm{Ti}$, the equilibrium oxide phase was a mixture of $\mathrm{Ti}_{3} \mathrm{O}_{5}$ and $\mathrm{Ti}_{2} \mathrm{O}_{3}$. Therefore, the critical Ti content in liquid iron at which both $\mathrm{Ti}_{3} \mathrm{O}_{5}$ and $\mathrm{Ti}_{2} \mathrm{O}_{3}$ are the equilibrium oxide phases is experimentally determined as $0.25 \operatorname{mass} \%$ at $1873 \mathrm{~K}$ in the present study. The thermodynamic calculation of critical Ti content using the data obtained in the present study will be discussed later.

Figure 5 shows the equilibrium relations between $\mathrm{Ti}$ and $\mathrm{O}$ dissolved in liquid iron at $1873 \mathrm{~K}$ determined in the present study together with previous results. ${ }^{3,6,8,10,11)}$ The oxygen solubility minimum was about 7.7 mass ppm at 0.625 mass $\% \mathrm{Ti}$, and the Ti-O relation was not much affected by whether using a titanium oxide crucible or an $\mathrm{Al}_{2} \mathrm{O}_{3}$ crucible with titanium oxide powder at the bottom of the melt in the present study. As shown in the figure, the experimental results obtained by various equilibration techniques are widely dispersed. Fruehan ${ }^{11)}$ measured the oxygen activity 


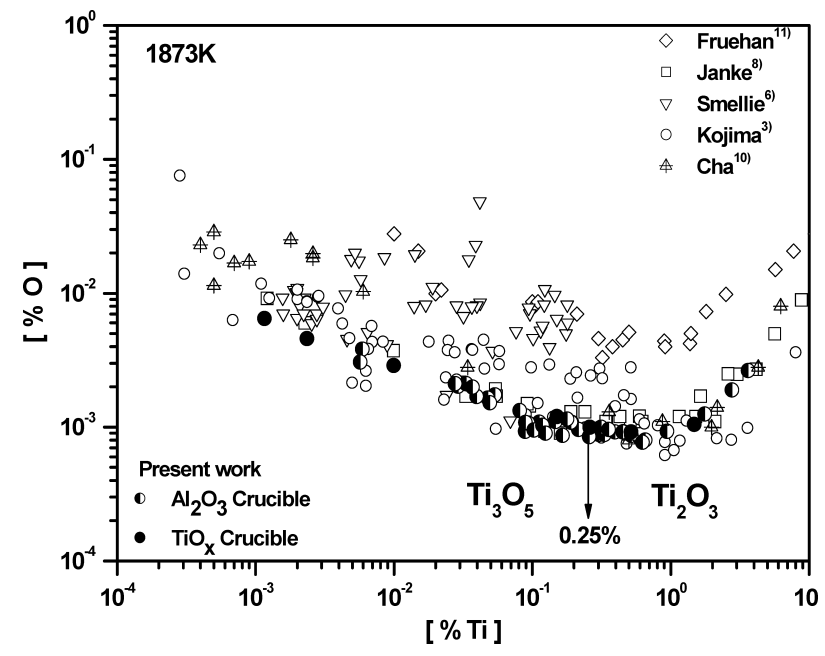

Fig. 5. Equilibrium relation between $[\% \mathrm{Ti}]$ and $[\% \mathrm{O}]$ in liquid iron at $1873 \mathrm{~K}$ together with previous results.

by the EMF method using $\mathrm{ZrO}_{2}(\mathrm{CaO})$ and $\mathrm{ThO}_{2}\left(\mathrm{Y}_{2} \mathrm{O}_{3}\right)$ electrolyte oxygen cells, and also determined the oxygen solubility by the sampling method in $\mathrm{Fe}-\mathrm{Ti}$ melts at $1873 \mathrm{~K}$. He used $\mathrm{ThO}_{2}$ and $\mathrm{ZrO}_{2}$ crucibles for the containers of $\mathrm{Fe}-\mathrm{Ti}$ melts. His oxygen solubility minimum was 33 mass ppm at 0.32 mass $\% \mathrm{Ti}$, and it is much higher than the others including the result of present study. The oxygen solubility data for $\mathrm{Fe}-\mathrm{Ti}$ melts determined by Smellie and Bell ${ }^{6}$ with $\mathrm{Al}_{2} \mathrm{O}_{3}$ and $\mathrm{Ti}_{3} \mathrm{O}_{5}$ crucibles, and Kojima et al. ${ }^{3)}$ with $\mathrm{Al}_{2} \mathrm{O}_{3}, \mathrm{MgO}$ and $\mathrm{CaO}$ crucibles are widely scattered. However, their data of lower oxygen content range are comparable to the data determined in the present study. Among those data, the results of present study are in good agreement with the studies by Janke and Fischer ${ }^{8)}$ and Cha et al. ${ }^{9}{ }^{10)}$ who used sintered titanium oxide crucibles.

Janke and Fischer investigated the Ti deoxidation equilibrium in liquid iron at $1873 \mathrm{~K}$ by the EMF method using a $\mathrm{ZrO}_{2}(\mathrm{CaO})-\mathrm{ThO}_{2}\left(\mathrm{Y}_{2} \mathrm{O}_{3}\right)$ bielectrolyte oxygen cell also by the sampling method ${ }^{8}$ They measured the oxygen activity and the oxygen content in liquid iron containing from 0.001 to $8.8 \mathrm{mass} \%$ Ti contained in sintered titanium oxide crucibles. The calculated the Ti activity in $\mathrm{Fe}-\mathrm{Ti}$ melts using the EMF data assuming the activities of titanium oxides are unity. In the present study, some trials were also made to measure the oxygen activity in $\mathrm{Fe}-\mathrm{Ti}$ melts using a $\mathrm{ZrO}_{2}(\mathrm{CaO})$ electrolyte oxygen cell. After the cell measurement, the electrolyte/melt interface was analyzed by the SEM-EDS as shown in Fig. 6. At a Ti content of 0.395 mass\% (Run 37), a pure titanium oxide was formed on the surface of the electrolyte. However, at about 0.18 mass $\% \mathrm{Ti}$ content (Run 28), there was a solid solution layer of titanium oxide and zirconium oxide formed at the electrolyte-melt interface as shown in the figure. Therefore, the oxygen activity measured by the oxygen cell would be affected by the purity or activity of titanium oxides formed at the $\mathrm{ZrO}_{2}$ electrolyte/melt interface depending on Ti content in $\mathrm{Fe}-\mathrm{Ti}$ melts. For this reason, the oxygen activity measurement for $\mathrm{Fe}-\mathrm{Ti}$ melts using $\mathrm{ZrO}_{2}$ electrolyte was not carried out further in the present study.

Recently, Cha et al. ${ }^{9,10)}$ also studied the equilibrium between $\mathrm{Ti}$ and $\mathrm{O}$ in liquid $\mathrm{Fe}-\mathrm{Ti}$ alloy contained in sintered $\mathrm{Ti}_{3} \mathrm{O}_{5}$ crucibles at $1873 \mathrm{~K}$. They emphasized the impor-

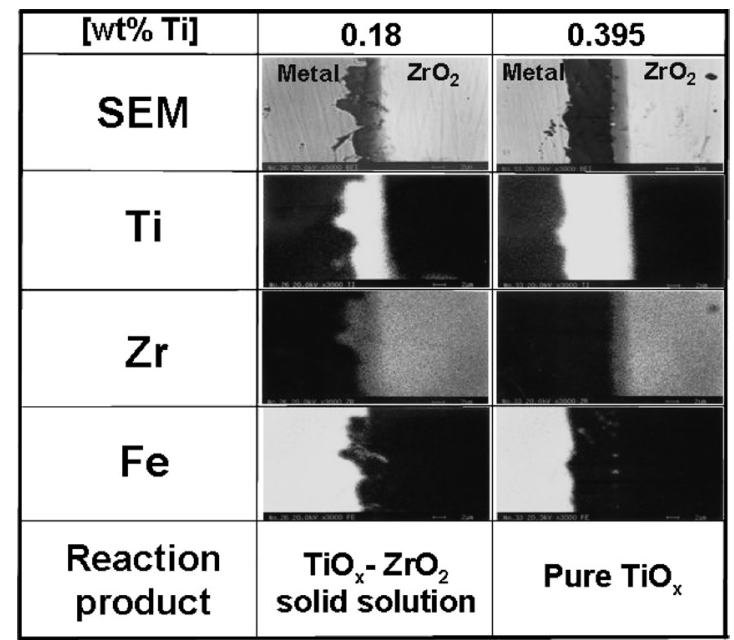

Fig. 6. SEM-EDS analysis results on the $\mathrm{ZrO}_{2}$ electrolyte/melt interface.
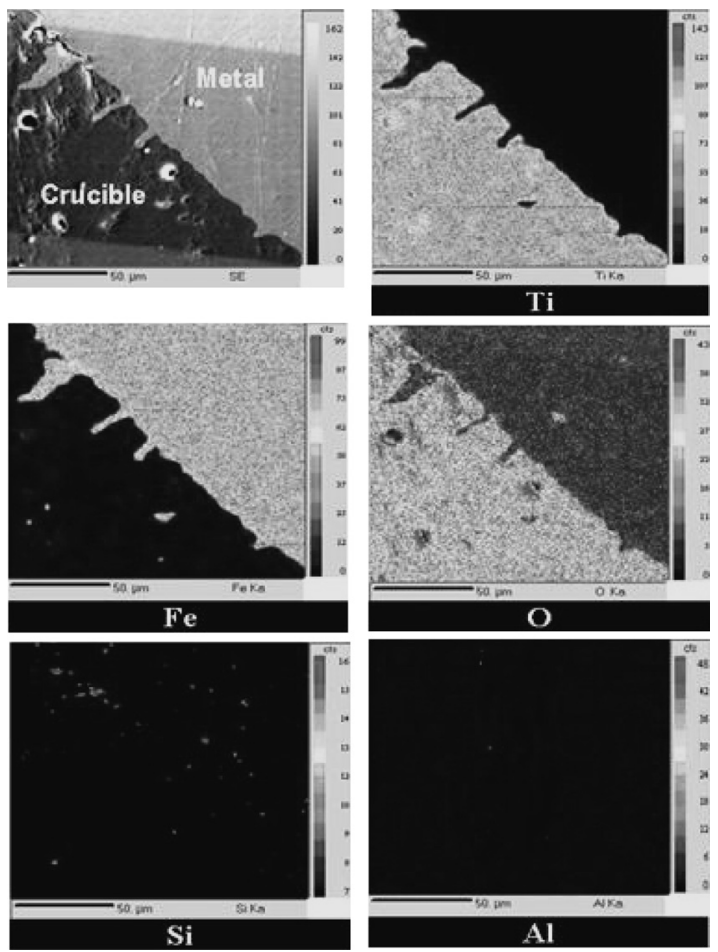

Fig. 7. EPMA analysis results on the $\mathrm{TiO}_{x}$ crucible/metal interface (Run 7)

tance of identification of equilibrium titanium oxide phases formed at the interface between the crucibles and Ti containing iron melt. They identified the equilibrium titanium oxide phases of $\mathrm{Ti}_{3} \mathrm{O}_{5}, \mathrm{Ti}_{2} \mathrm{O}_{3}$ and $\mathrm{TiO}$ formed at the interface as a function of $\mathrm{Ti}$ content in $\mathrm{Fe}-\mathrm{Ti}$ melts with the electron backscatter diffraction (EBSD) pattern analysis at $1873 \mathrm{~K}^{9}{ }^{9)}$ In the present study, the equilibrium titanium oxide phase was identified by the XRD analysis as $\mathrm{Ti}_{3} \mathrm{O}_{5}$ for alloys containing from 0.0012 to $0.25 \mathrm{mass} \% \mathrm{Ti}$, and $\mathrm{Ti}_{2} \mathrm{O}_{3}$ from 0.25 to 3.6 mass $\%$ Ti at $1873 \mathrm{~K}$. The purity or activity of equilibrium titanium oxides should be also considered for the accurate thermodynamic analysis of Ti deoxidation equilibria. Figure 7 shows the result of EPMA analysis on the crucible/metal interface after the Ti deoxidation experiment at 1.47 mass\% Ti content (Run 7). The oxide layer was virtually a pure titanium oxide phase free 
from other oxides of Fe, Si and Al. Suzuki et al. ${ }^{7)}$ measured the solid solubility of $\mathrm{FeO}_{t}$ in synthetic titanium oxide crucibles after the equilibration with Fe-Ti melts at $1873 \mathrm{~K}$. They reported that there was no solubility of $\mathrm{FeO}_{t}$ in $\mathrm{TiO}$ and $\mathrm{Ti}_{2} \mathrm{O}_{3}$, but there was an increasing solubility of $\mathrm{FeO}_{t}$ in titanium oxides of higher $\mathrm{O} / \mathrm{Ti}$ ratio (1.67-2: $\mathrm{Ti}_{3} \mathrm{O}_{5}$ and $\mathrm{TiO}_{2}$ ) as shown in Fig. 8. ${ }^{7}$

In the present study, some of Ti deoxidation experiments were carried out using $\mathrm{Al}_{2} \mathrm{O}_{3}$ crucibles with titanium oxide powder located at the bottom of the crucible. Ti in the melt would react with $\mathrm{Al}_{2} \mathrm{O}_{3}$ to dissolve some $\mathrm{Al}$ in the melt and form titanium oxides as following reaction;

$$
\underline{\mathrm{Ti}}+\frac{x}{3} \mathrm{Al}_{2} \mathrm{O}_{3}(\mathrm{~s})=\frac{2 x}{3} \underline{\mathrm{Al}}+\mathrm{TiO}_{x}(\mathrm{~s})
$$

Therefore, it is important to give a consideration for the equilibrium titanium oxide phase which may be formed at the interface between $\mathrm{Al}_{2} \mathrm{O}_{3}$ crucibles and $\mathrm{Fe}-\mathrm{Ti}$ melt. The inner surface of $\mathrm{Al}_{2} \mathrm{O}_{3}$ crucibles were examined by the SEM-EDS after the Ti deoxidation experiments. However, no reaction layer was observed on the surface of $\mathrm{Al}_{2} \mathrm{O}_{3}$ crucible. Instead, there was a thin titanium oxide layer formed on the surface of the melt when the Ti content was higher than 0.2 mass $\%$ in Fe-Ti melt. Figure 9 shows the SEMEDS analysis results on the titanium oxide layers formed on the melt surface and $\mathrm{Al}_{2} \mathrm{O}_{3}$ crucible/melt interface for the

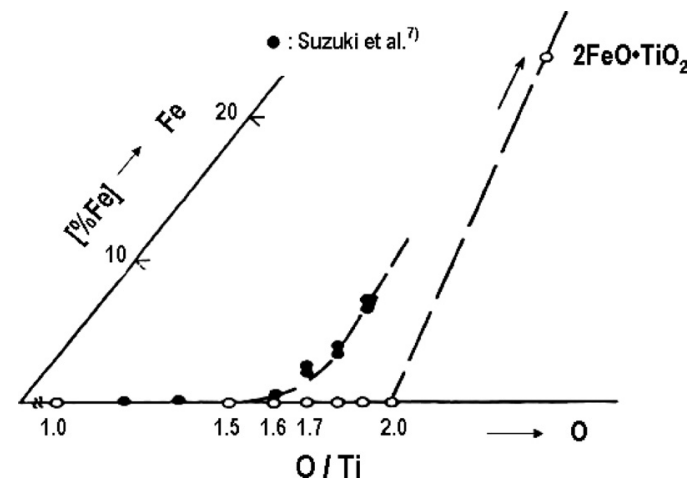

Fig. 8. The solid solubility of $\mathrm{FeO}_{t}$ in titanium oxide at $1873 \mathrm{~K}$ melt containing 1.76 mass $\%$ Ti (Run 43). The oxide layers were virtually pure titanium oxide phases free from other constituents. The thin film XRD analysis on top oxide layer identified the deoxidation product as $\mathrm{Ti}_{2} \mathrm{O}_{3}$ as shown in Fig. 10. Therefore, considering the results in Figs. 7, 9 and 10, it can be concluded that pure solid $\mathrm{Ti}_{2} \mathrm{O}_{3}$ is the equilibrium deoxidation product for $\mathrm{Fe}-\mathrm{Ti}$ melts at $\mathrm{Ti}$ contents higher than 0.25 mass $\%$ at $1873 \mathrm{~K}$, regardless of using a titanium oxide crucible or an $\mathrm{Al}_{2} \mathrm{O}_{3}$ crucible with titanium oxide powder at the bottom of the melt in the present study.

\subsection{Thermodynamics of Ti Deoxidation in Liquid Iron for $\mathrm{Ti}_{2} \mathrm{O}_{3}$ Formation}

The deoxidation reaction of $\mathrm{Ti}$ to form $\mathrm{Ti}_{2} \mathrm{O}_{3}$ in liquid iron and its equilibrium constant can be expressed by Eqs. (2) and (3):

$$
2 \underline{\mathrm{Ti}}+3 \underline{\mathrm{O}}=\mathrm{Ti}_{2} \mathrm{O}_{3}(\mathrm{~s})
$$

$$
\begin{aligned}
\log K_{\mathrm{Ti}_{2} \mathrm{O}_{3}} & =\log \left(a_{\mathrm{Ti}_{2} \mathrm{O}_{3}} / h_{\mathrm{Ti}}^{2} \cdot h_{\mathrm{O}}^{3}\right) \\
& =\log \left(a_{\mathrm{Ti}_{2} \mathrm{O}_{3}} / f_{\mathrm{Ti}}^{2} \cdot[\% \mathrm{Ti}]^{2} \cdot f_{\mathrm{O}}^{3} \cdot[\% \mathrm{O}]^{3}\right)
\end{aligned}
$$

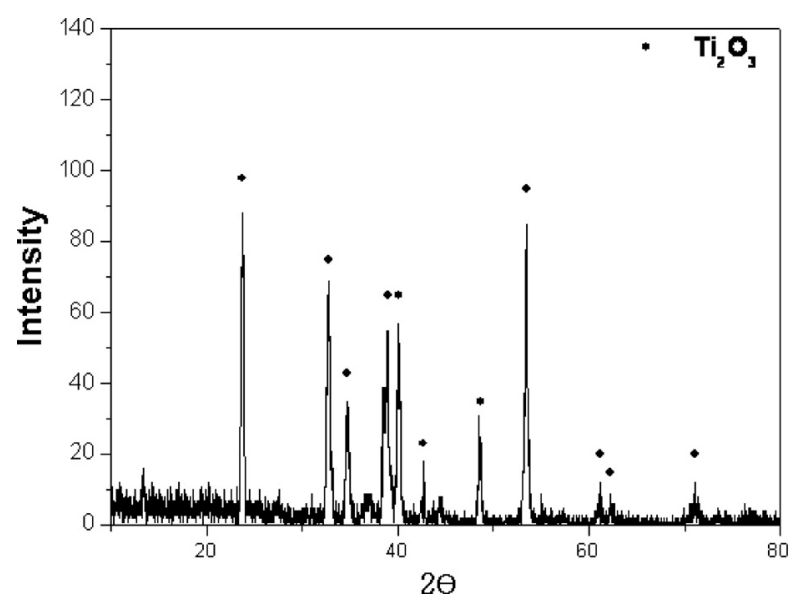

Fig. 10. Thin film XRD patterns for $\mathrm{TiO}_{x}$ layer formed on the melt surface at $1873 \mathrm{~K}$ (Run 43).

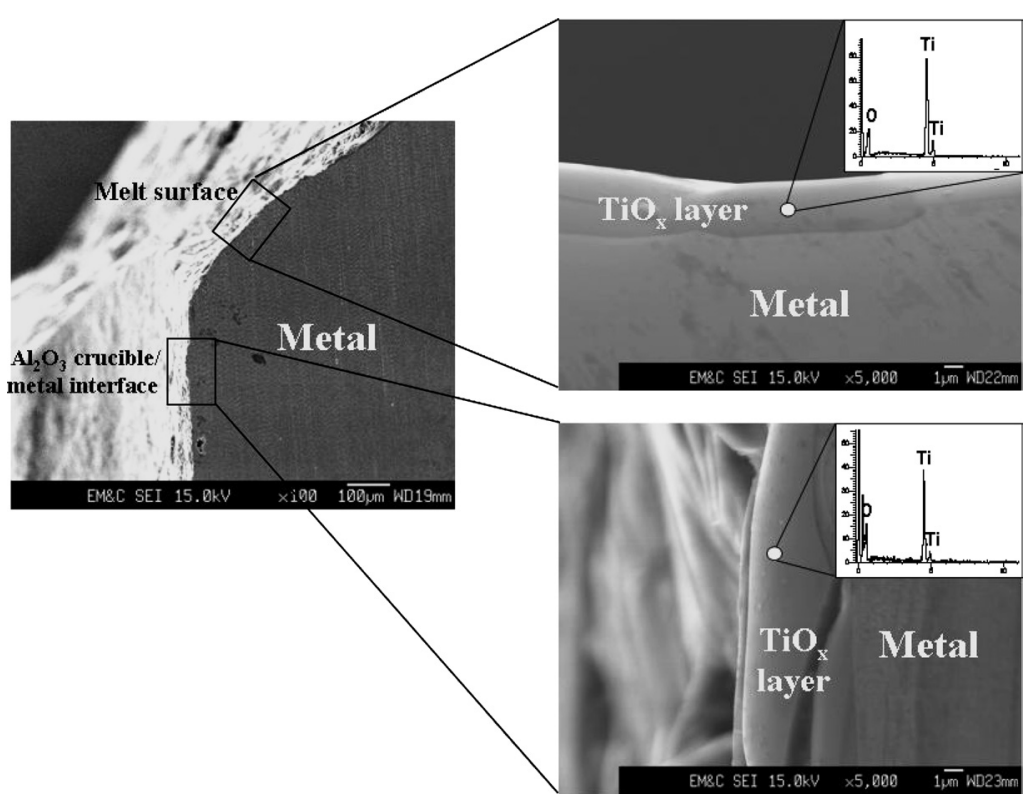

Fig. 9. SEM-EDS analysis results of $\mathrm{TiO}_{x}$ layer formed on the melt surface at $1873 \mathrm{~K}$ (Run 43). 
Table 2. Interaction parameters used in the present study.

\begin{tabular}{|c|c|c|c|}
\hline & $\mathbf{1 8 7 3 K}$ & Temp. Dependency & Reference \\
\hline \multirow{2}{*}{$e_{T i}^{T i}$} & 0.048 & - & 8 \\
\cline { 2 - 4 } & 0.048 & $1873 \sim 1973 \mathrm{~K}$ & 18 \\
\hline$e_{T i}^{A l}$ & 0.0037 & - & 19 \\
\hline$e_{T i}^{S i}$ & -0.0256 & $177.5 / \mathrm{T}-0.12$ & 20 \\
\hline$e_{O}^{O}$ & -0.17 & $-1750 / \mathrm{T}+0.76$ & 2 \\
\hline$e_{O}^{A l}$ & -1.17 & - & 2 \\
\hline$e_{O}^{S i}$ & -0.066 & $1823 \sim 1923 \mathrm{~K}$ & 2 \\
\hline
\end{tabular}

where $K_{\mathrm{Ti}_{2} \mathrm{O}_{3}}, a_{\mathrm{Ti}_{2} \mathrm{O}_{3}}, h_{i}$ and $f_{i}$ and are the equilibrium constant, the Raoultian activity, the Henrian activity and the Henrian activity coefficient, respectively. The standard states of $h_{\mathrm{Ti}}$ and $h_{\mathrm{O}}$ are their infinitely dilute solution in liquid iron, and that of $a_{\mathrm{Ti}_{2} \mathrm{O}_{3}}$ is pure solid $\mathrm{Ti}_{2} \mathrm{O}_{3}$. The activity coefficients of $\mathrm{Ti}$ and $\mathrm{O}$ in liquid iron can be expressed by Wagner's relation $^{13)}$ using the first- and second-order interaction parameters.

$$
\begin{aligned}
\log f_{\mathrm{Ti}}=e_{\mathrm{Ti}}^{\mathrm{Ti}}[\% \mathrm{Ti}] & +r_{\mathrm{Ti}}^{\mathrm{Ti}}[\% \mathrm{Ti}]^{2}+e_{\mathrm{Ti}}^{\mathrm{O}}[\% \mathrm{O}]+r_{\mathrm{Ti}}^{\mathrm{O}}[\% \mathrm{O}]^{2} \\
& +r_{\mathrm{Ti}}^{\mathrm{Ti}, \mathrm{O}}[\% \mathrm{Ti}][\% \mathrm{O}]
\end{aligned}
$$

$$
\begin{aligned}
\log f_{\mathrm{O}}=e_{\mathrm{O}}^{\mathrm{O}}[\% \mathrm{O}] & +r_{\mathrm{O}}^{\mathrm{O}}[\% \mathrm{O}]^{2}+e_{\mathrm{O}}^{\mathrm{Ti}}[\% \mathrm{Ti}]+r_{\mathrm{O}}^{\mathrm{Ti}}[\% \mathrm{Ti}]^{2} \\
& +r_{\mathrm{O}}^{\mathrm{Ti}, \mathrm{O}}[\% \mathrm{Ti}][\% \mathrm{O}]
\end{aligned}
$$

Using only the first-order interaction parameters and the Lupis' reciprocal relationship ${ }^{17)}$ between $e_{\mathrm{Ti}}^{\mathrm{O}}$ and $e_{\mathrm{O}}^{\mathrm{Ti}}$, Eq. (3) can be rewritten as the following relation:

$$
\begin{array}{r}
-\log K_{\mathrm{Ti}_{2} \mathrm{O}_{3}}^{\prime}+\log a_{\mathrm{Ti}_{2} \mathrm{O}_{3}}-\sum 2 e_{\mathrm{Ti}}^{k}[\% k]-\sum 3 e_{\mathrm{O}}^{l}[\% l] \\
=e_{\mathrm{Ti}}^{\mathrm{O}}(2[\% \mathrm{O}]+1.002[\% \mathrm{Ti}])+\log K_{\mathrm{Ti}_{2} \mathrm{O}_{3}} \ldots . . .
\end{array}
$$

Where $K_{\mathrm{Ti}_{2} \mathrm{O}_{3}}^{\prime}\left(=[\% \mathrm{Ti}]^{2} \cdot[\% \mathrm{O}]^{3}\right)$ is the apparent equilibrium constant, $k$ and $l$ represent elements other than $\mathrm{O}$ and Ti, respectively, and the value of $a_{\mathrm{Ti}_{2} \mathrm{O}_{3}}$ is unity in the present study. When $\mathrm{Al}$ and $\mathrm{Si}$ are present in liquid iron, the interaction parameters of those elements on $\mathrm{Ti}$ and $\mathrm{O}$ should be also considered. The interaction parameters used in the present study are summarized in Table 2 . $^{2,8,18-20)}$

Figure 11 shows a plot for the relation expressed by Eq. (6) using the present experimental data for iron melts containing $0.26-0.94$ mass $\% \mathrm{Ti}$ at $1873 \mathrm{~K}$. It is apparent from the figure that the data points determined at different $\mathrm{Ti}$ contents show a good linear relationship. The value of $\log K_{\mathrm{Ti}_{2} \mathrm{O}_{3}}$ obtained by extrapolating the line is found to be approximately 10.62 at $1873 \mathrm{~K}$. The values of $\log K_{\mathrm{Ti}_{2} \mathrm{O}_{3}}$ at $1873 \mathrm{~K}$ previously reported are in the range of 9.9-11.69 as shown in Table $3^{2-8,10-12,21,22)}$ Among those values, the present data is in good agreement with the values of 10.39 determined by Búzěk ${ }^{5)}$ and 10.43 determined by Janke and Fischer $^{8)}$ at $1873 \mathrm{~K}$.

The value of $e_{\mathrm{Ti}}^{\mathrm{O}}$ can be obtained from the slope of the line as -1.62 , and $e_{\mathrm{O}}^{\mathrm{Ti}}$ as -0.541 using the reciprocal relationship. ${ }^{17)}$ The recommended value of the Japan Society for the Promotion of Science (JSPS) ${ }^{2)}$ for $e_{\mathrm{O}}^{\mathrm{Ti}}$ is -1.12 at $1873 \mathrm{~K}$ taken from the data reported by Fruehan. ${ }^{11)}$ However, considering a rough estimation of $e_{\mathrm{O}}^{\mathrm{Ti}}$ from the nonlinear plot of $\log f_{\mathrm{o}} v$. Ti content over a wide composition range of $0.02-12.5$ mass $\% \mathrm{Ti}$, this value does not seem to

\begin{tabular}{|c|c|c|c|c|}
\hline $\begin{array}{c}\text { Equilibrium } \\
\text { Phase }\end{array}$ & $\log K$ & $e_{O}^{T_{i}}$ & $r_{O}^{T i}$ & Reference \\
\hline $\begin{array}{l}\mathrm{Ti}_{3} \mathrm{O}_{5} \\
\mathrm{Ti}_{2} \mathrm{O}_{3}\end{array}$ & $\begin{array}{l}18.71 \\
11.53\end{array}$ & - & & 21 \\
\hline $\begin{array}{l}\mathrm{Ti}_{3} \mathrm{O}_{5} \\
\mathrm{Ti}_{2} \mathrm{O}_{3} \\
\end{array}$ & $\begin{array}{l}19.26 \\
11.69 \\
\end{array}$ & $\begin{array}{c}-1.0 \\
-0.42 \\
\end{array}$ & & 22 \\
\hline $\mathrm{Ti}_{3} \mathrm{O}_{5}$ & 17.4 & -0.37 & & 3 \\
\hline $\mathrm{Ti}_{2} \mathrm{O}_{3}$ & 9.90 & -0.65 & & 4 \\
\hline $\begin{array}{l}\mathrm{Ti}_{3} \mathrm{O}_{5} \\
\mathrm{Ti}_{2} \mathrm{O}_{3} \\
\end{array}$ & $\begin{array}{l}17.56 \\
10.39 \\
\end{array}$ & $\begin{array}{l}-4.79 \\
-0.75 \\
\end{array}$ & & 5 \\
\hline $\mathrm{Ti}_{3} \mathrm{O}_{5}$ & 18.5 & -5.0 & & 6 \\
\hline $\mathrm{Ti}_{3} \mathrm{O}_{5}$ & $* 16.10$ & -0.31 & & 7 \\
\hline $\begin{array}{l}\mathrm{Ti}_{3} \mathrm{O}_{5} \\
\mathrm{Ti}_{2} \mathrm{O}_{3} \\
\end{array}$ & $\begin{array}{l}17.13 \\
10.43 \\
\end{array}$ & - & & 8 \\
\hline $\begin{array}{l}\mathrm{Ti}_{3} \mathrm{O}_{5} \\
\mathrm{Ti}_{2} \mathrm{O}_{3} \\
\end{array}$ & $\begin{array}{l}16.86 \\
10.17 \\
\end{array}$ & -0.34 & & 10 \\
\hline \multirow[t]{2}{*}{ - } & - & $*-1.12$ & & 11 \\
\hline & & -0.6 & 0.031 & 12 \\
\hline $\begin{array}{l}\mathrm{Ti}_{3} \mathrm{O}_{5} \\
\mathrm{Ti}_{2} \mathrm{O}_{3} \\
\end{array}$ & $\begin{array}{l}17.56 \\
10.62 \\
\end{array}$ & -0.541 & 0.0385 & Present study \\
\hline
\end{tabular}

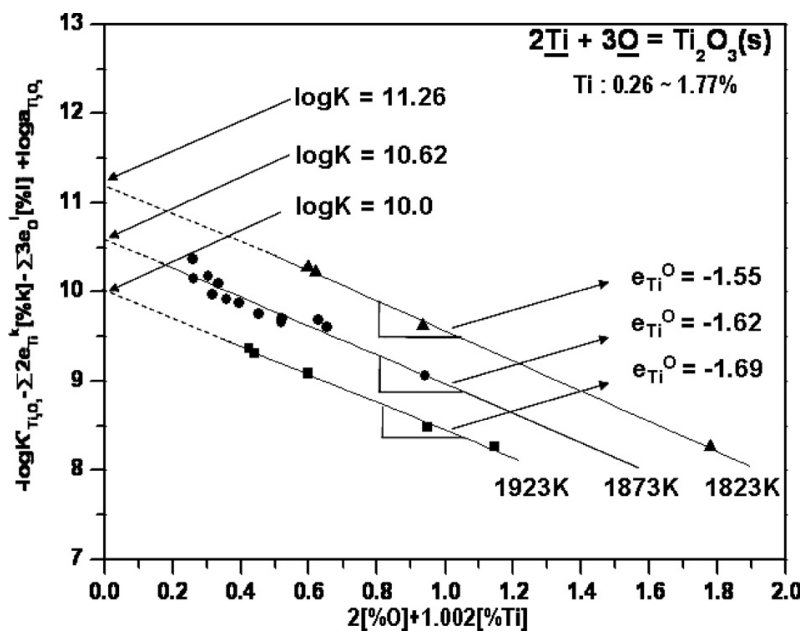

Fig. 11. Relation of Eq. (6) to determine $e_{\mathrm{Ti}}^{\mathrm{O}}$ and $\log K_{\mathrm{Ti}_{2} \mathrm{O}_{3}}$ values.

Table 3. $\log K$ of Ti deoxidation and interaction parameters of $\mathrm{Ti}$ and $\mathrm{O}$ in liquid iron at $1873 \mathrm{~K}$.

be a reliable one to use. Sigworth and Elliott recalculated the first- and second-order interaction parameters of $e_{\mathrm{O}}^{\mathrm{Ti}}$ and $r_{\mathrm{O}}^{\mathrm{Ti}}$ using Fruehan's experimental data ${ }^{11)}$ as -0.6 and 0.031 at $1873 \mathrm{~K}$, respectively, and compiled them in their thermodynamic data of liquid dilute iron alloys. ${ }^{12)}$

In the present study, the equilibrium relations between $\mathrm{Ti}$ and $\mathrm{O}$ in liquid iron at temperatures other than $1873 \mathrm{~K}$ were also measured. Figure 12 compares the Ti-O relations measured at $1823 \mathrm{~K}$ and $1923 \mathrm{~K}$ using titanium oxide crucibles for iron melts containing $0.42-4.75 \mathrm{mass} \% \mathrm{Ti}$ together with data obtained at $1873 \mathrm{~K}$. The equilibrium titanium oxide phases at this Ti concentration range at $1823 \mathrm{~K}$ and $1923 \mathrm{~K}$ were all identified as pure solid $\mathrm{Ti}_{2} \mathrm{O}_{3}$. By the same procedure using Eq. (6), the equilibrium constants for the reaction (2) and the first-order interaction parameters between $\mathrm{Ti}$ and $\mathrm{O}$ at $1823 \mathrm{~K}$ and $1923 \mathrm{~K}$ can be also determined as shown in Fig. 11.

Figure 13 shows the temperature dependences of $\log K_{\mathrm{Ti}_{2} \mathrm{O}_{3}}$ and $e_{\mathrm{O}}^{\mathrm{Ti}}$ values determined in the present study, and they can be expressed as Eqs. (7) and (8) in the temperature range of 1823 to $1923 \mathrm{~K}$. 


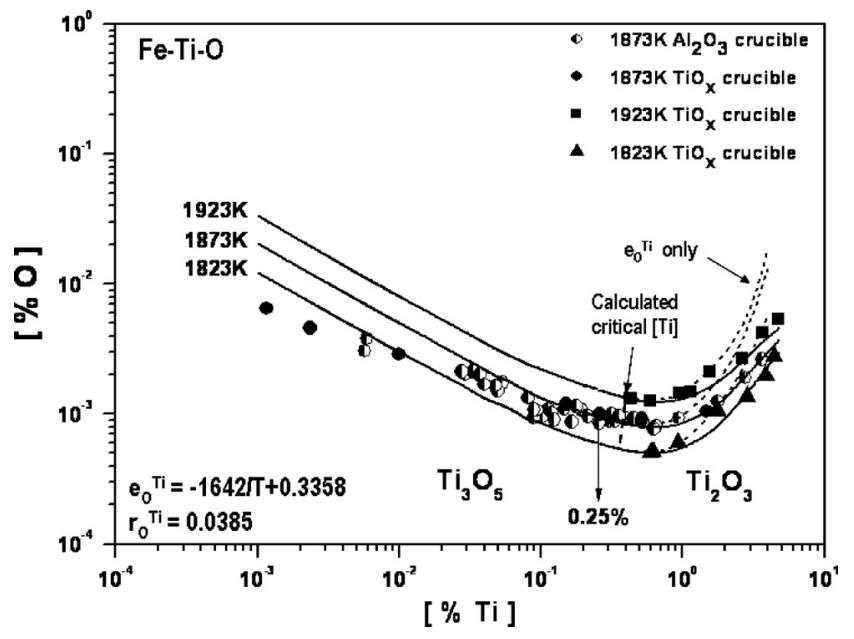

Fig. 12. Relations between $[\% \mathrm{Ti}]$ and $[\% \mathrm{O}]$ in liquid iron at 1823,1873 and $1923 \mathrm{~K}$.

$$
\log K_{\mathrm{Ti}_{2} \mathrm{O}_{3}}=44238 / T-13.0
$$

$$
e_{\mathrm{O}}^{\mathrm{Ti}}=-1642 / T+0.3358 \text { or } e_{\mathrm{Ti}}^{\mathrm{O}}=-4915 / T+1.005
$$

In the preceding discussion, the first order $e_{\mathrm{Ti}}^{\mathrm{O}}$ values were determined from the experimental data of $\mathrm{Ti}$ and $\mathrm{O}$ relation for the melts containing $0.26-1.77$ mass $\%$ Ti. At a higher Ti concentration in liquid iron, higher order interaction parameters should be considered. If the second-order interaction parameters are also considered in Eqs. (4) and (5), Eq. (3) can be rewritten as the following relation:

$$
\begin{aligned}
-\log K_{\mathrm{Ti}_{2} \mathrm{O}_{3}}-\log K_{\mathrm{Ti}_{2} \mathrm{O}_{3}}^{\prime}+\log a_{\mathrm{Ti}_{2} \mathrm{O}_{3}} & \\
- & 2 \sum e_{\mathrm{Ti}}^{k}[\% k]-\sum e_{\mathrm{O}}^{l}[\% l]+0.00414[\% \mathrm{Ti}][\% \mathrm{O}] \\
& \quad-e_{\mathrm{Ti}}^{\mathrm{O}}(2[\% \mathrm{O}]+1.002[\% \mathrm{Ti}]-0.03[\% \mathrm{Ti}][\% \mathrm{O}]) \\
= & r_{\mathrm{Ti}}^{\mathrm{O}}\left(2[\% \mathrm{O}]^{2}+2.005[\% \mathrm{Ti}][\% \mathrm{O}]\right) \\
& +r_{\mathrm{O}}^{\mathrm{Ti}}\left(3[\% \mathrm{Ti}]^{2}+11.97[\% \mathrm{Ti}][\% \mathrm{O}]\right) \ldots \ldots \ldots \ldots \ldots . . . . . . . . . . . .(9)
\end{aligned}
$$

where $k$ and $l$ represent the same meanings as in Eq. (6), and $\log K_{\mathrm{Ti}_{2} \mathrm{O}_{3}}$ and $e_{\mathrm{Ti}}^{\mathrm{O}}$ were determined previously as Eqs. (7) and (8), respectively. The values of $r_{\mathrm{Ti}}^{\mathrm{Ti}}$ and $r_{\mathrm{O}}^{\mathrm{O}}$ are assumed as zero in the present study. The cross product terms of $r_{\mathrm{O}}^{\mathrm{Ti}, \mathrm{O}}$ and $r_{\mathrm{Ti}}^{\mathrm{Ti} \mathrm{O}}$ can be expressed as a function of $r_{\mathrm{O}}^{\mathrm{Ti}}$ and $r_{\mathrm{Ti}}^{\mathrm{O}}$, respectively, using the following relationships ${ }^{17)}$ :

$$
\begin{aligned}
& r_{\mathrm{Ti}}^{\mathrm{Ti}, \mathrm{O}}=2\left(\frac{M_{\mathrm{Ti}}}{M_{\mathrm{O}}}\right) r_{\mathrm{O}}^{\mathrm{Ti}}+0.01 e_{\mathrm{Ti}}^{\mathrm{Ti}}-0.01 e_{\mathrm{Ti}}^{\mathrm{O}} \\
& r_{\mathrm{O}}^{\mathrm{Ti}, \mathrm{O}}=2\left(\frac{M_{\mathrm{O}}}{M_{\mathrm{Ti}}}\right) r_{\mathrm{Ti}}^{\mathrm{O}}+0.01 e_{\mathrm{O}}^{\mathrm{O}}-0.01 e_{\mathrm{O}}^{\mathrm{Ti}}
\end{aligned}
$$

Therefore, all terms in Eq. (9) are known values except the second-order interaction parameters, $r_{\mathrm{O}}^{\mathrm{Ti}}$ and $r_{\mathrm{Ti}}^{\mathrm{O}}$. These parameters can be determined from the experimental data of $\mathrm{Ti}$ and $\mathrm{O}$ relation for the melts containing 1.474.75 mass \% Ti. Figure 14 shows the relation of Eq. (9) in which both sides are divided by the term $\left(2[\% \mathrm{O}]^{2}+\right.$ $2.005[\% \mathrm{Ti}][\% \mathrm{O}])$ at 1823,1873 and $1923 \mathrm{~K}$. The temper-

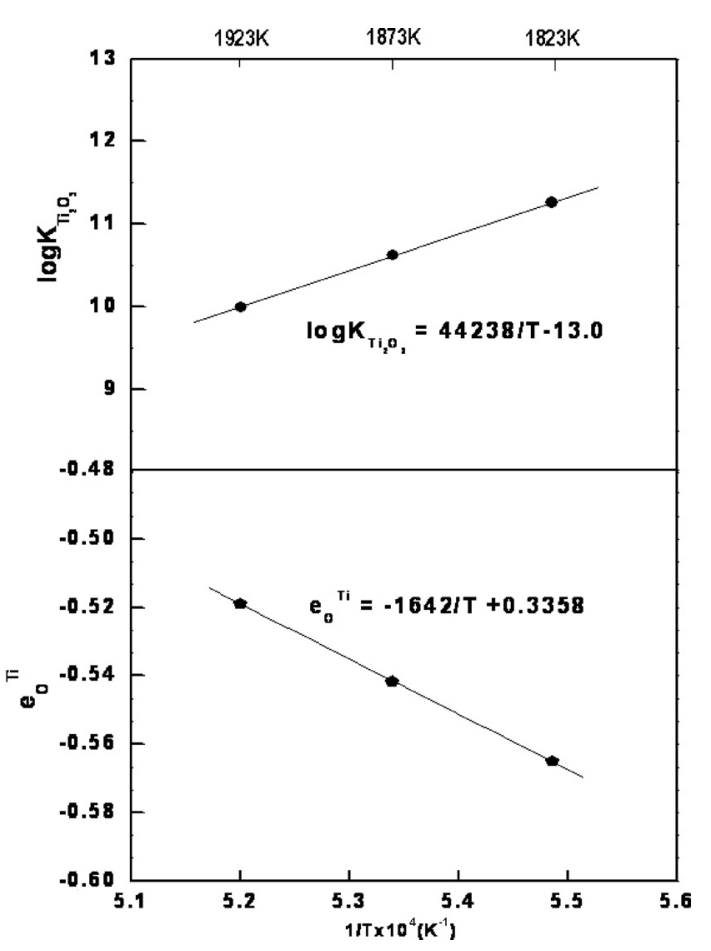

Fig. 13. Temperature dependences of $\log K_{\mathrm{Ti}_{2} \mathrm{O}_{3}}$ and $e_{\mathrm{O}}^{\mathrm{Ti}}$ values.

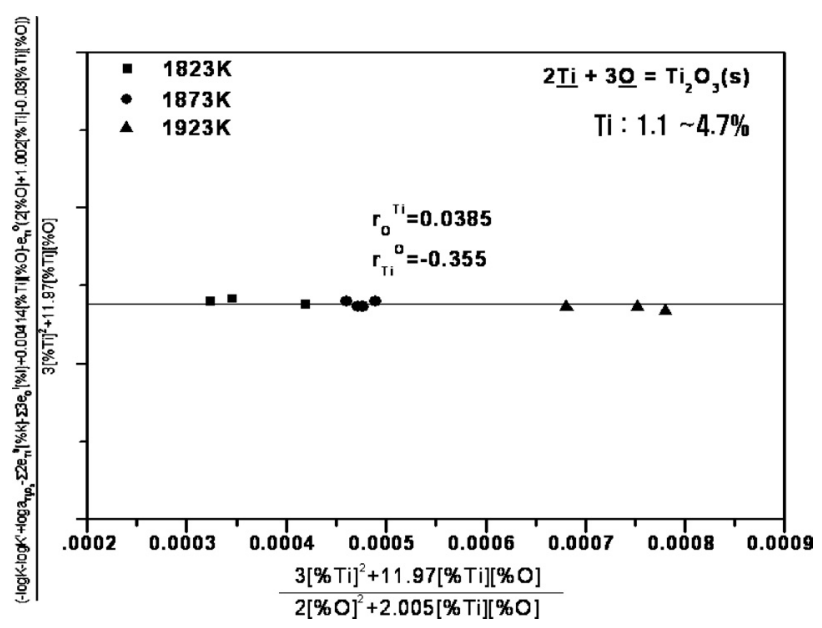

Fig. 14. Relation of Eq. (9) to determine $r_{\mathrm{O}}^{\mathrm{Ti}}$ and $r_{\mathrm{Ti}}^{\mathrm{O}}$ values.

ature dependence of the relation was negligible. The values of and determined by a linear regression analysis are 0.0385 and -0.355 , respectively. The second-order $r_{\mathrm{O}}^{\mathrm{Ti}}$ value of 0.0385 is in good agreement with the value of 0.031 at $1873 \mathrm{~K}$ reported by Sigworth and Elliott. ${ }^{12)}$

The values of interaction parameters between $\mathrm{Ti}$ and $\mathrm{O}$ and the equilibrium constant for the reaction (2) determined in the present study are summarized in Table 4. Using the thermodynamic parameters determined in the present study, the Ti deoxidation product for the formation of pure solid $\mathrm{Ti}_{2} \mathrm{O}_{3}$ in $\mathrm{Fe}-\mathrm{Ti}-\mathrm{O}$ melt can be derived as Eq. (12).

$$
\begin{aligned}
& \log [\% \mathrm{Ti}]^{2}[\% \mathrm{O}]^{3} \\
&=-(44238 / T-13.0) \\
&-(-4915 / T+1.005)(2[\% \mathrm{O}]+1.002[\% \mathrm{Ti}]) \\
&-2\left(e_{\mathrm{Ti}}^{\mathrm{Ti}}[\% \mathrm{Ti}]+r_{\mathrm{Ti}}^{\mathrm{O}}[\% \mathrm{O}]^{2}+r_{\mathrm{Ti}}^{\mathrm{Ti}, \mathrm{O}}[\% \mathrm{Ti}][\% \mathrm{O}]\right. \\
&-3\left(e_{\mathrm{O}}^{\mathrm{O}}[\% \mathrm{O}]+r_{\mathrm{O}}^{\mathrm{Ti}}[\% \mathrm{Ti}]^{2}+r_{\mathrm{O}}^{\mathrm{Ti}, \mathrm{O}}[\% \mathrm{Ti}][\% \mathrm{O}]\right)
\end{aligned}
$$


Table 4. The equilibrium constants and interaction parameters determined in the present study.

\begin{tabular}{|c|c|c|}
\hline & $\mathbf{1 8 7 3 K}$ & Temp. Dependency \\
\hline$e_{O}^{T i}$ & -0.541 & $-1642 / \mathrm{T}+0.3358$ \\
\hline$e_{T i}^{O}$ & -1.620 & $-4915 / \mathrm{T}+1.005$ \\
\hline$r_{O}^{T i}$ & 0.0385 & $1823 \sim 1923 \mathrm{~K}$ \\
\hline$r_{T i}^{O}$ & -0.355 & $1823 \sim 1923 \mathrm{~K}$ \\
\hline $\log K_{T i_{2} O_{3}}$ & 10.62 & $44238 / \mathrm{T}-13.0$ \\
\hline $\log K_{T i_{3} O_{5}}$ & 17.56 & $72813 / \mathrm{T}-21.32$ \\
\hline
\end{tabular}

In Fig. 12, the solid lines shown in the Ti concentration range higher than 0.25 mass $\%$ are the calculated equilibrium $\mathrm{Ti}-\mathrm{O}$ relations in liquid iron for the formation of $\mathrm{Ti}_{2} \mathrm{O}_{3}$ (s) at 1823,1873 and $1923 \mathrm{~K}$ using Eq. (12), assuming the activity of $\mathrm{Ti}_{2} \mathrm{O}_{3}(\mathrm{~s})$ as unity. The calculated relations well represent the experimental results obtained over a wide range of $\mathrm{Ti}$ content. The dotted lines shown in the same $\mathrm{Ti}$ concentration range are the calculated $\mathrm{Ti}-\mathrm{O}$ relations using only the first order interaction parameters. The dotted lines show a good correlation with the experimental results at $\mathrm{Ti}$ contents less than 1 mass\%. However, they deviate from the experimental results significantly at higher $\mathrm{Ti}$ contents.

From the temperature dependence of equilibrium constant for the Ti deoxidation reaction expressed as Eq. (7), the following Gibbs free energy change for the reaction (2) can be derived in the temperature range of 1823 to $1923 \mathrm{~K}$.

$$
\begin{gathered}
2 \underline{\mathrm{Ti}}+3 \underline{\mathrm{O}}=\mathrm{Ti}_{2} \mathrm{O}_{3}(\mathrm{~s}) \ldots \ldots \ldots \ldots . . . \\
\Delta G_{2}=-845928+248.6 T \mathrm{~J} / \mathrm{mol} .
\end{gathered}
$$

The standard Gibbs free energy change for the formation of $\mathrm{Ti}_{2} \mathrm{O}_{3}(\mathrm{~s})$ is given by NIST-JANAF ${ }^{14)}$ as Eq. (15).

$$
\begin{gathered}
2 \mathrm{Ti}(\mathrm{s})+3 / 2 \mathrm{O}_{2}(\mathrm{~g})=\mathrm{Ti}_{2} \mathrm{O}_{3}(\mathrm{~s}) \ldots \ldots \\
\Delta G_{14}^{\circ}=-1502126+258.08 T \mathrm{~J} / \mathrm{mol}^{14)}
\end{gathered}
$$

Combination of Eqs. (13), (15) and the free energy change data for the dissolution of oxygen in liquid iron ${ }^{15}$ given as Eq. (17) would give the free energy change for the dissolution of Ti in liquid iron as Eq. (19).

$$
\begin{aligned}
& 1 / 2 \mathrm{O}_{2}(\mathrm{~g})=\underline{\mathrm{O}} \\
& \Delta G_{16}=-117122-2.88 T \mathrm{~J} / \mathrm{g} \cdot \text { atom }^{15)} \\
& \mathrm{Ti}(\mathrm{s})=\underline{\mathrm{Ti}} \\
& \Delta G_{18}=-152416+9.07 T \mathrm{~J} / \mathrm{g} \cdot \text { atom }
\end{aligned}
$$

From Eq. (19), one would be able to calculate the value of $\gamma_{\mathrm{T}}^{\circ}$, the activity coefficient of Ti in liquid iron at infinite dilution, as $0.011,0.014$ and 0.018 at $1823 \mathrm{~K}, 1873 \mathrm{~K}$ and $1923 \mathrm{~K}$, respectively. Table 5 compares these values together with previous results. ${ }^{2,22-24)}$
Table 5. Henrian activity coefficient of $\mathrm{Ti}, \gamma_{\mathrm{Ti}}^{\mathrm{o}}$ in liquid iron at $1873 \mathrm{~K}$.

\begin{tabular}{|c|c|c|}
\hline \multicolumn{1}{|c|}{$\gamma_{T_{i}}^{o}$} & Method & Reference \\
\hline 0.011 & $\begin{array}{c}\text { Estimated from } \\
\text { Hadley's data }\end{array}$ & 23 \\
\hline 0.033 & $\begin{array}{c}\text { Thermodynamic evaluation } \\
\text { using experimental data }\end{array}$ & 24 \\
\hline 0.038 & EMF & 11 \\
\hline 0.050 & Estimated from experimental data & 7 \\
\hline 0.016 & $\begin{array}{c}\text { Thermodynamic evaluation } \\
\text { using experimental data }\end{array}$ & 25 \\
\hline$* 0.018$ & $\begin{array}{c}\text { Knudsen Cell } \\
\text { Mass Spectrometry }\end{array}$ & 26 \\
\hline 0.018 & EMF & 10 \\
\hline 0.009 & $\begin{array}{c}\text { Thermodynamic evaluation } \\
\text { using experimental data }\end{array}$ & $\begin{array}{c}\text { Present } \\
\text { study }\end{array}$ \\
\hline $\begin{array}{l}0.011 \text { at } 1823 \mathrm{~K} \\
0.014 \text { at } 1873 \mathrm{~K} \\
0.018 \text { at } 1923 \mathrm{~K}\end{array}$ & $\begin{array}{c}\text { Thermodynamic evaluation } \\
\text { using experimental data }\end{array}$ & \\
\hline
\end{tabular}

\subsection{Thermodynamic Assessment of Ti Deoxidation Reaction for $\mathrm{Ti}_{3} \mathrm{O}_{5}$ Formation}

In the present study, the equilibrium titanium oxide phase was identified as $\mathrm{Ti}_{3} \mathrm{O}_{5}$ for iron melts containing from 0.0012 to 0.25 mass $\% \mathrm{Ti}$ at $1873 \mathrm{~K}$. The standard Gibbs free energy change for the formation of pure solid $\mathrm{Ti}_{3} \mathrm{O}_{5}$ is given by NIST-JANAF ${ }^{14)}$ as Eq. (21).

$$
\begin{gathered}
3 \mathrm{Ti}(\mathrm{s})+5 / 2 \mathrm{O}_{2}(\mathrm{~g})=\mathrm{Ti}_{3} \mathrm{O}_{5}(\mathrm{~s}) \ldots \ldots \\
\left.\Delta G_{20}^{\circ}=-2435202+420.5 T \mathrm{~J} / \mathrm{mol}^{14}\right)
\end{gathered}
$$

Combination of Eqs. (17), (19) and (21) would give the free energy change for $\mathrm{Ti}$ deoxidation reaction in liquid iron to form $\mathrm{Ti}_{3} \mathrm{O}_{5}(\mathrm{~s})$ as:

$$
\begin{gathered}
3 \underline{\mathrm{Ti}}+5 \underline{\mathrm{O}}=\mathrm{Ti}_{3} \mathrm{O}_{5}(\mathrm{~s}) \\
\Delta G_{22}=-1392344+407.7 T \mathrm{~J} / \mathrm{g} \cdot \text { atom }
\end{gathered}
$$

Therefore, the Ti deoxidation product for the formation of pure solid $\mathrm{Ti}_{3} \mathrm{O}_{5}$ in $\mathrm{Fe}-\mathrm{Ti}-\mathrm{O}$ melt can be derived as Eq. (24).

$$
\begin{aligned}
& \log [\% \mathrm{Ti}]^{3}[\% \mathrm{O}]^{5} \\
&=-(72813 / T-21.32) \\
&-(4915 / T+1.005) \cdot(3[\% \mathrm{O}]+1.67[\% \mathrm{Ti}]) \\
&-3\left(e_{\mathrm{Ti}}^{\mathrm{Ti}}[\% \mathrm{Ti}]+r_{\mathrm{Ti}}^{\mathrm{O}}[\% \mathrm{O}]^{2}+r_{\mathrm{Ti}}^{\mathrm{Ti}, \mathrm{O}}[\% \mathrm{Ti}][\% \mathrm{O}]\right) \\
&-5\left(e_{\mathrm{O}}^{\mathrm{O}}[\% \mathrm{O}]+r_{\mathrm{O}}^{\mathrm{Ti}}[\% \mathrm{Ti}]^{2}+r_{\mathrm{O}}^{\mathrm{Ti}, \mathrm{O}}[\% \mathrm{Ti}][\% \mathrm{O}]\right)
\end{aligned}
$$

In Fig. 12, the solid lines shown in the Ti concentration range lower than 0.25 mass $\%$ are the calculated equilibrium $\mathrm{Ti}-\mathrm{O}$ relations in liquid iron for the formation of $\mathrm{Ti}_{3} \mathrm{O}_{5}(\mathrm{~s})$ at 1823,1873 and $1923 \mathrm{~K}$ using Eq. (24), assuming the activity of $\mathrm{Ti}_{3} \mathrm{O}_{5}$ (s) as unity. However, it can be seen that the experimental results of $\mathrm{Ti}-\mathrm{O}$ relation at $1873 \mathrm{~K}$ deviate from the calculated relation at the same temperature. The deviation becomes more significant when Ti content decreases below 0.01 mass $\%$ in liquid iron. As discussed ear- 
lier, Suzuki and Sanbongi ${ }^{7)}$ found that there was a significant solubility of $\mathrm{FeO}_{t}$ in titanium oxides with $\mathrm{O} / \mathrm{Ti}$ ratio higher than $1.67\left(\mathrm{Ti}_{3} \mathrm{O}_{5}\right)$ after the equilibration with liquid iron containing low Ti contents. Recently, Cha et al. ${ }^{9)}$ also found that the solid solubility of $\mathrm{FeO}_{t}$ in $\mathrm{Ti}_{3} \mathrm{O}_{5}$ phase increased significantly when the $\mathrm{Ti}$ content in liquid iron decreased below 0.01 mass $\%$ at $1873 \mathrm{~K}$. Therefore, such deviation at low $\mathrm{Ti}$ contents in the present study can be explained by the activity of $\mathrm{Ti}_{3} \mathrm{O}_{5}$ being less than unity due to the solid solution of $\mathrm{FeO}_{t}$ in $\mathrm{Ti}_{3} \mathrm{O}_{5}$ phase.

\subsection{Critical Ti Content in Liquid Iron for $\mathrm{Ti}_{2} \mathrm{O}_{3}$ and $\mathrm{Ti}_{3} \mathrm{O}_{5}$ Formation}

In the present study, the critical Ti content in liquid iron at which both $\mathrm{Ti}_{3} \mathrm{O}_{5}$ and $\mathrm{Ti}_{2} \mathrm{O}_{3}$ coexisted was experimentally determined as 0.25 mass $\%$ at $1873 \mathrm{~K}$. Cha et al. ${ }^{9)}$ recently estimated the critical Ti content in liquid iron for coexistence of $\mathrm{Ti}_{3} \mathrm{O}_{5}$ and $\mathrm{Ti}_{2} \mathrm{O}_{3}$ phases as 0.526 at $1873 \mathrm{~K}$ using the standard free energies of titanium oxide formation $^{14)}$ and their activity data of $\mathrm{Ti}$ in liquid iron at $1873 \mathrm{~K}^{10)}$

From Eqs. (13) and (23), the following Gibbs free energy change for the reaction (25) can be derived.

$$
\begin{gathered}
\underline{\mathrm{Ti}}+3 \mathrm{Ti}_{3} \mathrm{O}_{5}(\mathrm{~s})=5 \mathrm{Ti}_{2} \mathrm{O}_{3}(\mathrm{~s}) \ldots \ldots . \\
\Delta G_{24}=-52608+19.9 \mathrm{~T} \mathrm{~J} / \mathrm{g} \cdot \text { atom }
\end{gathered}
$$

Equilibrium constant of Eq. (24) can be expressed as

$$
\begin{aligned}
\log K_{24} & =\log \left(a_{\mathrm{Ti}_{2} \mathrm{O}_{3}}^{5} / h_{\mathrm{Ti}} \cdot a_{\mathrm{Ti}_{3} \mathrm{O}_{5}}^{3}\right) \\
& =-\log h_{\mathrm{Ti}}=-\left(\log f_{\mathrm{Ti}}+\log [\% \mathrm{Ti}]\right) \\
& =-\left(e_{\mathrm{Ti}}^{\mathrm{Ti}}[\% \mathrm{Ti}]+e_{\mathrm{Ti}}^{\mathrm{O}}[\% \mathrm{O}]+\log [\% \mathrm{Ti}]\right)
\end{aligned}
$$

Where the activities of both $\mathrm{Ti}_{3} \mathrm{O}_{5}$ and $\mathrm{Ti}_{2} \mathrm{O}_{3}$ are assumed to be unity, the value of $e_{\mathrm{Ti}}^{\mathrm{Ti}}$ used in this study is $0.048^{8,18)}$ at $1823-1873 \mathrm{~K}$, and the effect of oxygen on the Ti activity is assumed to be negligible due to its extremely small content. The critical Ti contents satisfying the Eq. (26) can be calculated as $0.33,0.36$ and 0.39 mass $\%$ at 1823,1873 and $1923 \mathrm{~K}$, respectively. They are also shown in Fig. 12. The critical Ti content of 0.36 mass $\%$ Ti estimated at $1873 \mathrm{~K}$ is slightly higher than 0.25 mass $\%$ Ti determined experimentally in the present study.

\section{Conclusions}

The relation of $\mathrm{Ti}$ and $\mathrm{O}$ dissolved in liquid iron equilibrated with solid titanium oxides has been determined in the temperature range of 1823 to $1923 \mathrm{~K}$. The equilibrium titanium oxide phase was identified as $\mathrm{Ti}_{3} \mathrm{O}_{5}$ for $\mathrm{Fe}-\mathrm{Ti}$ alloys containing from 0.0012 to 0.21 mass $\% \mathrm{Ti}$, and $\mathrm{Ti}_{2} \mathrm{O}_{3}$ for alloys containing from 0.26 to 3.6 mass $\%$ Ti at $1873 \mathrm{~K}$. The critical Ti content in liquid iron at which both $\mathrm{Ti}_{3} \mathrm{O}_{5}$ and $\mathrm{Ti}_{2} \mathrm{O}_{3}$ coexist was experimentally determined as $0.25 \mathrm{mass} \%$ at $1873 \mathrm{~K}$. The equilibrium constants of Ti deoxidation reactions for the formation of pure solid $\mathrm{Ti}_{2} \mathrm{O}_{3}$ and $\mathrm{Ti}_{3} \mathrm{O}_{5}$, and the first- and second-order interaction parameters between $\mathrm{Ti}$ and $\mathrm{O}$ in liquid iron were determined as a function of temperature given by the following equa- tions.

$$
\begin{gathered}
2 \underline{\mathrm{Ti}}+3 \underline{\mathrm{O}}=\mathrm{Ti}_{2} \mathrm{O}_{3}(\mathrm{~s}) \quad(0.25<\operatorname{mass} \% \mathrm{Ti}<4.75) \\
\log K_{\mathrm{Ti}_{2} \mathrm{O}_{3}}=44238 / T-13.0 \\
3 \underline{\mathrm{Ti}}+5 \underline{\mathrm{O}}=\mathrm{Ti}_{3} \mathrm{O}_{5}(\mathrm{~s}) \quad(0.0012<\operatorname{mass} \% \mathrm{Ti}<0.25) \\
\log K_{\mathrm{Ti}_{3} \mathrm{O}_{5}}=72813 / T-21.32 \\
e_{\mathrm{O}}^{\mathrm{Ti}}=-1642 / T+0.3358, \quad e_{\mathrm{Ti}}^{\mathrm{O}}=-4915 / T+1.005 \\
r_{\mathrm{O}}^{\mathrm{Ti}}=0.0385, \quad r_{\mathrm{Ti}}^{\mathrm{O}}=-0.355
\end{gathered}
$$

In addition, the activity coefficient of $\mathrm{Ti}$ in liquid iron at infinite dilution, $\gamma_{\mathrm{Ti}(\mathrm{s})}^{\mathrm{o}}$ was assessed as $0.011,0.014$ and 0.018 at $1823 \mathrm{~K}, 1873 \mathrm{~K}$ and $1923 \mathrm{~K}$, respectively.

\section{Acknowledgments}

The present work was financially supported by POSCO (Grant No.: 2004Z021). The authors also wish to thank Mr. Gil-Yeol Ryu, RIST, Pohang for help with the analysis by EPMA.

\section{REFERENCES}

1) Y. D. Lee and S. H. Park: J. Korean Inst. Met. Mater, 31 (1993), 984.

2) Steelmaking Data Sourcebook; The Japan Society for the Promotion of Science, The 19th Committee on Steelmaking, Gordon and Breach Science Publishers, New York, (1988), 165.

3) Y. Kojima, M. Inoue and J. Ohi: Arch. Eisenhüttenwes., 40 (1969), 667.

4) V. I. Yavoyskii, L. B. Kosterev, A. A. Ayub and L. N. Rastorguev: Russ. Metall., 2 (1971), 33.

5) Z. Búzěk: Proc. Int. Symp. On Metall. Chem. Application in ferrous Metallurgy, University Of Sheffield, United Kingdom, 2, (1971), 173.

6) A. M. Smellie and B. H. Bell: Can. Metall. Q., 11 (1972), 351.

7) K. Suzuki and K. Sanbongi: Trans. Iron Steel Inst. Jpn., 15 (1975), 618.

8) D. Janke and W. A. Fischer: Arch. Eisenhüttenwes, 47 (1976), 195.

9) W. Y. Cha, T. Miki, Y. Sasaki and M. Hino: ISIJ Int., 46 (2006), 987.

10) W. Y. Cha, T. Nagasaka, T. Miki, Y. Sasaki and M. Hino: ISIJ Int., 46 (2006), 996.

11) R. J. Fruehan: Metall. Trans., 1 (1970), 3403.

12) G. K. Sigworth and J. F. Elliott: Met. Sci., 8 (1974), 298.

13) C. Wagner: Thermodynamics of Alloys, Addison-wesley Press, Cambridge, Mass., (1952), 47.

14) NIST-JANAF Thermochemical Tables, 4th ed., Amer. Chem. Soc., Westerbille, Ohio, (1998).

15) E. T. Turkdogan: Physical Chemistry of High Temperature Technology, Academic Press, New York, (1980), 81.

16) W. G. Seo, W. H. Han, J. S. Kim and J. J. Pak: ISIJ Int., 43 (2003), 201.

17) C. H. P. Lupis and J. F. Elliott: Acta Metall., 14 (1966), 529.

18) W. Y. Kim, J. O. Jo, S. I. Kim, T. I. Chung, J. G. Kang and J. J. Pak: Hanyang University, Ansan, Korea, unpublished research, (2006).

19) G. Yuanchang and W. Changchen: Metall. Trans. B., 21B (1990), 543.

20) J. J. Pak, J. T. Yoo, Y. S. Jeong, S. J. Tae, S. M. Seo, D. S. Kim and Y. D. Lee: ISIJ Int., 45 (2005), 23.

21) K. Segawa, E. Tsunetomi, Y. Nakamura and H. Chino: Trans. Iron Steel Inst. Jpn., 9 (1969), 89.

22) A. Ghosh and G. V. R. Murthy: Trans. Iron Steel Inst. Jpn., 26 (1986), 628.

23) J. Chipman: Trans. Met. Sci. AIME., 218 (1960), 767.

24) H. Chino, Y. Nakamura, E. Tsunetomi and K. Segawa: Tetsu-toHagané, 52 (1966), 959.

25) T. Furukawa and E. Kato: Tetsu-to-Hagané, 61 (1975), 3060.

26) H. Y. Choi, W. E. Slye, R. J. Fruehan and R. C. Nunnington: Metall. Mater. Trans. B., 36B (2005), 537. 